Ševala Isaković-Kaplan, $\mathrm{PhD}^{1}$

Lejla Demirović, $\mathrm{PhD}^{2}$

Mahir Proho, BSc

\title{
FINANCIAL REPORTING OF BUSINESS ENTITIES AND ETHICAL DILEMMAS OF STUDENTS IN BOSNIA AND HERZEGOVINA
}

\begin{abstract}
The fair and reliable financial reporting of business entities is extremely important for strengthening the confidence among business entities, acting positively on the scope of business activities and achieved results. On the other hand, individuals, businesses and the entire society, suffered huge losses, due to the frauds in financial reports, by dropping the confidence in the accounting profession. The public's expectations from the accounting profession are that its professionals consciously reject participation in any fraud activities, and be real fighters for the real financial reporting of the entities. In the light of specified expectations, this paper tries to consider the ability of students of economic specialization in Bosnia and Herzegovina in recognizing cases of false financial reporting among different situations that can(not) include fraud characteristics, and their readiness to take active participation in the fight against frauds in business entities and economic crimes, in general.

The results of the research showed that research participants clearly recognize cases of false financial reporting among various fraudulent activities, that they have a high level of awareness regarding the seriousness of the fraud type and its negative consequences for entities, and that they express their unreserved readiness to report these cases to the competent authorities with the purpose of prosecution.
\end{abstract}

Keywords: financial reports, fraud, accounting profession, ethics.

JEL: $M 49$

1 Associate Professor, School of Economic and Business, Trg oslobođenja - Alija Izetbegović 1, Sarajevo.

2 Assistant Professor, School of Economic and Business, Trg oslobođenja - Alija Izetbegović 1, Sarajevo. 


\section{INTRODUCTION}

The great accounting scandals in the early 21 st century recorded in globally renowned companies such as: Enron, WorldCom, Tyco, etc., characterized the global accounting scene and seriously shook confidence in the accounting profession. Unfortunately, the practice of financial reporting in $\mathrm{BiH}$, also, are populated with numerous examples of abuse of the fair financial reporting principles. (Isaković-Kaplan, 2016). Consequently, doubts appeared with reason, in the boundless need to meet investor goals, the creditor expectations, the wishes of the management, as well as the interests of others referred to the business activities and result of the company, is there is an entity which does not use with various frauds, or which is not the victim of frauds?

It is unnecessary to elaborate here the importance of high-quality financial reporting for companies, but it is important to note that the same can only be achieved with complete and proper implementation of the relevant legislative framework. This task: the proper and complete application of the provisions of the legislative framework in companies is entrusted to accountants, while auditors are dealing with the task of evaluating the compliance of the business operations with the relevant legislative framework. Unfortunately, accounting information system instead of poviding an objective record of all events that have occurred in the company, often becomes a polygon for numerous and various misappropriations. The negative consequences of this situation attack, directly and closely, the accounting profession, because trust in the same as the direct perpetrator of the frauds or profession that missed the opportunity to prevent or timely detect frauds is collapsing. (Isaković-Kaplan, 2019)

\section{Review of Relevant Literature}

Association of Certified Fraud Examiners ${ }^{3}$ (ACFE) published results which show that companies lose $5 \%$ of their revenues annually due to frauds, which is applied to gross world product amounts to more than $\$ 7$ billion of losses. $(2018$, p.9) ACFE reports group frauds into three groups: assets misappropriation (AM), corruption (C) and fraudulent financial statements (FFS), and the frequency of occurrence and the losses caused, through the last four reports, were shown in Table 1.

3 ACFE is the largest global professional organization dedicated to the fight against frauds, which has dealt with detecting frauds and reducing the risk of fraud worldwide continuously and devotedly since 1988 . 
Table 1: Relevant characteristics of frauds according to ACFE reports

\begin{tabular}{|c|c|c|c|c|c|c|c|c|}
\hline \multirow{3}{*}{ Type of fraud } & \multicolumn{8}{|c|}{ Frequency of fraud detection and average loss per fraud } \\
\hline & \multicolumn{2}{|c|}{2012} & \multicolumn{2}{|c|}{2014} & \multicolumn{2}{|c|}{2016} & \multicolumn{2}{|c|}{2018} \\
\hline & $\%$ & $\$$ & $\%$ & $\$$ & $\%$ & $\$$ & $\%$ & $\$$ \\
\hline Assets misappropriation & 87 & 120.000 & 85 & 130.000 & 83 & 125.000 & 89 & 114.000 \\
\hline Corruption & 33 & 250.000 & 37 & 200.000 & 35 & 200.000 & 38 & 250.000 \\
\hline Fraudulent financial statements & 8 & 1.000 .000 & 9 & 1.000 .000 & 10 & 975.000 & 10 & 800.000 \\
\hline
\end{tabular}

Source: ACFE Reports to the Nations - Global Study on Occupational Fraud and Abuse 2012-2018

The data presented in Table 1 indicate a general increase in the number of fraud cases detected in entities over the observed period, and FFS cases present financially the heaviest form of fraud that can occur in a company, with frequency of occurrence of $10 \%$ and an average loss of $\$ 800,000$ according to the last report, while comparisons for, the number of FFS cases detected in the ACFE report 2010 was a decent 5\% (2010, p.4) Additionally, the last ACFE report shows that the highest number of fraud detected (14\%) were created in the accounting department by causing an average loss of $\$ 212,000$, in front of the operations department $(14 \%, \$ 88,000)$, sales $(12 \%, \$ 90,000)$ and executive management $(11 \%, \$ 729,000)$. $(2018$, p.37). The situation is extra concerned by the fact, that in the fraud of other departments, and specifically in executive management fraud, the accounting department often has own contribution, because numerous frauds, and especially FFS fraud, are impossible to realize without the active role of an accountant.

The information presented in the ACFE report 2018 was based on data from 2,690 fraud cases detected in 125 countries in the two-year period 2016-2017, and it can be said that research provided a global view on frauds. (2018, p.7) Unfortunately research conducted by Pricewaterhouse Coopers - PWC Global Economic Crime and Fraud Survey 2018, as the largest international economic crime survey worldwide, with including 7,200 respondents in 123 countries, found that $49 \%$ of companies covered by research were victims of fraud in the last 24 months. $(2018, \mathrm{p} .2)$

ACFE reports indicate that the most significant source of information about frauds in the companies is tips (40\%), among which employees lead with their tips (53\%). (2018, p.17) The figures above suggest that we need to work on greater employee education on understanding and recognizing frauds in entities, as well as popularization and protection the so-called whistle-blowers in companies.

The experience of renowned authors in the field of forensic accounting and the fraud examination indicated that ,the most business graduates would not recognize a fraud if it hit them between the eyes ". (Albrecht et al., 2009, p.363) How successful in identifying frauds are the students of business studies in $\mathrm{BiH}$ will be demonstrated 
by this paper. Otherwise, students' perceptions of fraud and generally different ethical dilemmas were the subject of interest from various authors. (Baird \& Zelin II, 2008; Baird, Zelin II \& Olson, 2016; Aljinović Barać, Markota \& Vuljan, 2016)

\section{Research Methodology}

\subsection{Questionnaire}

Students' perceptions of fraud in $\mathrm{BiH}$, for the purposes of this paper, have been examined through research based on the application of the scenario methodology. For this purpose, set of six practical fraud scenarios was taken from the article "Understanding Employee Perceptions of Fraudulent Activities and Their Propensity to Report Those Activities Using Anonymous Tip Lines: The Influence of Fraud Type, Perpetrator Gender, and Observer Demographics" by authors Baird \& Zelin II. (2008) These fraud scenarios, for research purpose in $\mathrm{BiH}$, were minimally adapted to $\mathrm{BH}$ opportunities, by changing the name of the perpetrator of the fraud and monetary units in which fraud was expressed, in order to the respondents have the higher perception of the hypothetical situations from the questionnaire as a real frauds in $\mathrm{BiH}$, as a prerequisite for giving the most realistic and reliable answers. In addition, in order to provide the observers' neutrality to the fraudulent scenarios, the authors of this paper called the fraudster in each scenario by the same name. On this way, respondents did not perceive some fraud as more difficult based only to the negative attitude that they may have towards persons with certain name, and reverse. The questionnaire contained six scenarios with detailed description of incurred frauds in company, and frauds summary was presented in Table 2 .

Table 2: Table 2. Summary fraud scenario

\begin{tabular}{|c|l|c|}
\hline Scenario & \multicolumn{1}{|c|}{ Summary frauds } & Fraud type \\
\hline 1 & $\begin{array}{l}\text { Payment of benefits to employee for costs that have not "actually" incu- } \\
\text { rred. }\end{array}$ & AM \\
\hline 2 & $\begin{array}{l}\text { Acquisition of inventories at higher prices than market ones from a fami- } \\
\text { ly owned company of a director of purchasing sector. }\end{array}$ & C \\
\hline 3 & $\begin{array}{l}\text { Failure to record various expenses to maximize profits and make the } \\
\text { company more attractive to potential investors. }\end{array}$ & FFS \\
\hline 4 & $\begin{array}{l}\text { Records of working hours that employee did not "really" spend in the } \\
\text { company. }\end{array}$ & AM \\
\hline 5 & $\begin{array}{l}\text { Acquisition of inventories from a specific supplier with him the director } \\
\text { of purchasing sector has an agreed "arrangement" which implies that the } \\
\text { director receives a certain amount of cash for each order of inventories } \\
\text { from a given supplier. }\end{array}$ & C \\
\hline 6 & $\begin{array}{l}\text { Record of fictitious revenue to show profit and make the company more } \\
\text { successful for the purpose of applying to the bank for a loan. }\end{array}$ & FFS \\
\hline
\end{tabular}

Source: Adopted and customized (Baird \& Zelin II, 2008, p.6-7) 
Respondents were asked for an answer about the possibility of identifying fraud, understanding the seriousness of fraud, willingness to report the perpetrator of fraud, and agreement with described fraudulent actions. According to the author of this paper, the ethical dilemma of reporting a fraud perpetrator depends, first of all, on the existence / absence of a close relationship (for example: friendship, kinship or other close relationship) between the whistle-blower and the fraud perpetrator. Therefore, the issue of willingness to report fraud perpetrator from the original questionnaire for research purposes in $\mathrm{BiH}$ has been reformulated into two questions: the willingness to report fraud if the respondent is / isn't in close relationship with the fraud perpetrator.

For the purpose of identifying fraud, respondents chose between the basic types of fraud, while for the remaining questions they answered by using the Likert scale. To rating the level of fraud seriousness respondents used a scale from 1 - fraud wasn't committed to 7 - a highest level of fraud was committed, for the willingness to report fraud to the competent authorities the scale was used from 1 - definitely wouldn't report to 7 - definitely would report, while on the question of agreement with fraud committed the scale ranged from 1 - completely disagree to 7 - completely agree.

A total of 125 survey questionnaires were completed and the results of the survey were processed by using the SPSS statistical program.

\subsection{Expectations}

Results achieved from conducted research for each of the six individual scenarios were expressed by mean ratings. It is expected that scenarios that portray the same type fraud result in similar mean values, and that mean ratings for AM, C and FFS cases show a growing trend, respectively.

Since the willingness to report fraud depends on the perception of the fraud seriousness and as well as of the potential close relationship between the whistle-blower and fraud perpetrator, answers were analysed, with both assumptions: that the fraud perpetrator is in close relationship with the observer, and reverse. The expectation is that observers have a less intention to report fraud committed by close ones.

The agreement of the observer with fraudulent actions will be examined through the analysis of means between categories of fraud, with the intention to determination which fraud types the respondents are ready to repeat or commit themselves.

The assumptions of a negative correlation between the perception of fraud seriousness and agreement with the fraud actions, between the willingness to report fraud and the agreement with the committed fraud, and the positive correlation between 
the willingness to report fraud and the perception of the fraud seriousness will be examined by correlation analysis.

The general expectations regarding student's perception of FFS fraud as a central research question can be summarized as follows: respondents perceive FFS as the most serious form of fraud, show the most willingness to report FFS to the authorities, and state the minimum willingness to commit FFS fraud.

Based on the stated expectations, the following hypotheses were formulated:

H1: Respondents perceive FFS as a more serious fraud than AM,

H2: Respondents perceive FFS as a more serious fraud than C,

H3: Respondents perceive $C$ as a more serious fraud than $A M$,

H4: Respondents would rather report FFS fraud than AM,

H5: Respondents would rather report FFS fraud than C,

H6: Respondents would rather report $C$ fraud than $A M$,

H7: Respondents would rather report fraud when they have not close relationship with the fraud perpetrator, than when they have a close relationship with fraud perpetrator,

H8: Respondents express higher agreement with AM actions than $C$,

H9: Respondents express higher agreement with AM actions than FFS,

H10: Respondents express higher agreement with C actions than FFS.

\subsection{Research Results}

Firstly, participants were asked to recognize the fraud type for different scenarios in the questionnaire and their success in that task was presented in the following table.

Table 3: Identifying the fraud type

\begin{tabular}{|c|r|}
\hline Scenario & $\begin{array}{c}\text { The success of identifying the fraud type } \\
\text { expressed as a percentage }\end{array}$ \\
\hline 1 & 57,60 \\
\hline 2 & 22,40 \\
\hline 3 & 94,40 \\
\hline 4 & 61,60 \\
\hline 5 & 85,60 \\
\hline 6 & 96,80 \\
\hline
\end{tabular}

Source: Authors 
The data presented in Table 3 show that the respondents were the most successful in recognizing FFS frauds (Scenarios 3 and 6), while the worst result was recorded in identifying C from Scenario 2. Only $22.40 \%$ of respondents recognized the elements of $\mathrm{C}$ in the above case, while the majority (63.20\%) described this fraud as AM. Such results suggest that the observers recognize $C$ exclusively in the explicit relation with the given / taken bribe, and without the allegations about bribe they are not able to recognize the elements of $\mathrm{C}$ in practice. If the observers cannot recognize $\mathrm{C}$, they understand the same as AM, i.e. as a "milder" form of fraud, and in line with previously elaborated expectations, they will be more capable to commit this fraud and less interested to report it, which has a direct negative impact on the prevention and detection of $\mathrm{C}$ cases in $\mathrm{BiH}$.

Participants were asked to assess the fraud seriousness for described cases in questionnaire and their opinions were presented in Table 4.

Table 4: Perception of the fraud seriousness

\begin{tabular}{|c|r|r|r|r|r|}
\hline Scenario & \multicolumn{1}{|c|}{ N } & \multicolumn{1}{|c|}{ Minimum } & Maximum & Mean & \multicolumn{1}{c|}{ Std. Deviation } \\
\hline 1 & 125 & 1 & 7 & 3.29 & 1.795 \\
\hline 2 & 123 & 1 & 7 & 5.08 & 1.400 \\
\hline 3 & 124 & 2 & 7 & 6.24 & 1.070 \\
\hline 4 & 125 & 1 & 7 & 3.82 & 1.618 \\
\hline 5 & 124 & 2 & 7 & 6.06 & 1.057 \\
\hline 6 & 122 & 3 & 7 & 6.50 & .998 \\
\hline
\end{tabular}

Source: Authors

Research has shown that respondents considered cases 3 and 6 (FFS) with the highest mean ratings as the most serious form of fraud, while cases 1 and 4 (AM) were the least rated. It is important to note that for Scenario 6, the lowest rating given by respondents was 3, which shows the strict individual perceptions of respondents regarding the seriousness of this type of fraud. The Friedman test was used for testing the existence of statistically significant differences in respondents' answers to the question of the assessment of fraud seriousness, and it showed that, overall, there was a statistically significant difference in the perception of the severity of different types of fraud $(p=0.000)$. Further testing was focused on the existence of statistically significant differences in the perception of fraud severity, by fraud type, and on a case-by-case basis within the same type of fraud, and the Wilcoxon test was used for this purpose and its results were presented in Table 5. 
Table 5: Fraud seriousness by paired types and individual scenarios

\begin{tabular}{|l|r|r|r|r|r|r|}
\hline \multirow{2}{*}{ Fraud seriousness } & \multicolumn{4}{|c|}{ Paired fraud types } & \multicolumn{3}{c|}{ Paired fraud scenarios } \\
\cline { 2 - 7 } & \multicolumn{1}{|c|}{ FFS-AM } & \multicolumn{1}{|c|}{ FFS- C } & \multicolumn{1}{c|}{ C-AM } & \multicolumn{1}{c|}{ S6-S3 } & \multicolumn{1}{c|}{ S5-S2 } & \multicolumn{1}{c|}{ S4-S1 } \\
\hline$Z$ & $-12.714^{\mathrm{b}}$ & $-7.532^{\mathrm{b}}$ & $-11.062^{\mathrm{b}}$ & $-3.213^{\mathrm{b}}$ & $-6.048^{\mathrm{b}}$ & $-2.064^{\mathrm{b}}$ \\
\hline Asymp. Sig. (2-tailed) & .000 & .000 & .000 & .001 & .000 & .039 \\
\hline a. Wilcoxon Signed Ranks Test \\
\hline
\end{tabular}

\section{Source: Authors}

The Wilcoxon test showed a statistically significant difference in the perception of fraud severity both at the level of fraud types and within the same type of fraud, with the highest difference between the perception of fraud seriousness of FFS and AM, while at the individual case level the most expressed difference was observed between cases 2 and $5(\mathrm{C})$, since the respondents did not perceive case 2 as $\mathrm{C}$, assessing this case as so less serious.

Intention to report fraud activities to relevant authorities was presented in Tables 6-8.

Table 6: Willingness to report fraud

\begin{tabular}{|c|r|r|r|r|r|r|r|r|}
\hline \multirow{2}{*}{ Scenario } & \multirow{2}{*}{ Min } & \multirow{2}{*}{ Max } & \multicolumn{4}{|c|}{$\begin{array}{c}\text { The perpetrator and the } \\
\text { whistle-blower have no a } \\
\text { close relationship }\end{array}$} & \multicolumn{3}{|c|}{$\begin{array}{c}\text { The perpetrator and the } \\
\text { whistle-blower have a close } \\
\text { relationship }\end{array}$} \\
\cline { 4 - 9 } & & & N & Mean & Std. Dev. & N & Mean & Std. Dev. \\
\hline 1 & 1 & 7 & 125 & 3.62 & 2.209 & 124 & 3.02 & 2.111 \\
\hline 2 & 1 & 7 & 125 & 5.68 & 1.589 & 124 & 4.65 & 2.000 \\
\hline 3 & 1 & 7 & 123 & 5.73 & 1.635 & 122 & 5.09 & 1.988 \\
\hline 4 & 1 & 7 & 122 & 4.09 & 2.105 & 122 & 3.40 & 2.011 \\
\hline 5 & 1 & 7 & 124 & 5.95 & 1.481 & 123 & 5.28 & 1.875 \\
\hline 6 & 1 & 7 & 124 & 6.12 & 1.539 & 123 & 5.41 & 1.979 \\
\hline
\end{tabular}

Source: Authors

Table 6 shows that observers felt most strongly to report cases of FFS to the competent authorities, while they were least willing to report cases of AM, and in the conditions of close relations with the perpetrator of fraud, the survey results show a decline in whistle-blowers interest in reporting about fraud activities. It is interesting to compare the results of this research with the results presented in the paper by Baird \& Zelin II, which, for the scenarios 1-6, respectively, show the following mean ratings for intention to report the fraud perpetrator 3,$62 ; 4,83 ; 5,02 ; 4,58 ; 4,69 ; 4,76$. (2008, p.8) Comparison of presented results shows a greater willingness of observers in $\mathrm{BiH}$ to report FFS and $\mathrm{C}$, especially in the absence of a close relationship with the perpetrator, while in the context of close relationships with the perpetrator, $\mathrm{BiH}$ respondents are still more willing to report on the FFS scenario and case $\mathrm{C}$ with explicitly included bribe element. These extremely encouraging research findings in $\mathrm{BiH}$, which show the willingness of respondents to take an active part in the fight against 
fraud in companies, should be taken with caution, since the respondents answered during the study period, i.e., when they are not liable to different pressures from the environment, and it is questionable whether such a high willingness to report a fraud perpetrator will be expressed in the future in the workplace.

The Friedman test showed that there was a statistically significant difference in the willingness to report different types of fraud, regardless of the assumption that there is / is not close relationship with the perpetrator $(p=0.000)$.

Table 7: Willingness to report perpetrators by paired types and individual scenarios

\begin{tabular}{|l|r|r|r|r|r|r|}
\hline Willingness to report fraud & \multicolumn{3}{|c|}{$\begin{array}{c}\text { The perpetrator and the } \\
\text { whistle-blower have no close } \\
\text { relationship }\end{array}$} & \multicolumn{2}{c|}{$\begin{array}{c}\text { The perpetrator and the whistle- } \\
\text { blower have a close relationship }\end{array}$} \\
\hline Paired types of fraud & FFS-AM & FFS-C & C-AM & FFS-AM & FFS-C & C-AM \\
\hline Z & $-10.860 \mathrm{~b}$ & $-1.338 \mathrm{~b}$ & $-10.522 \mathrm{~b}$ & $-11.181 \mathrm{~b}$ & $-2.694 \mathrm{~b}$ & $-10.482 \mathrm{~b}$ \\
\hline Asymp. Sig. (2-tailed) & .000 & .181 & .000 & .000 & .007 & .000 \\
\hline Paired scenarios of fraud & $\mathrm{S} 6-\mathrm{S} 3$ & $\mathrm{~S} 5-\mathrm{S} 2$ & $\mathrm{~S} 4-\mathrm{S} 1$ & $\mathrm{~S} 6-\mathrm{S} 3$ & $\mathrm{~S} 5-\mathrm{S} 2$ & $\mathrm{~S} 4-\mathrm{S} 1$ \\
\hline Z & $-3.383 \mathrm{~b}$ & $-2.038 \mathrm{~b}$ & $-1.492 \mathrm{~b}$ & $-2.883 \mathrm{~b}$ & $-4.140 \mathrm{~b}$ & $-1.668 \mathrm{~b}$ \\
\hline Asymp. Sig. (2-tailed) & .001 & .042 & .136 & .004 & .000 & .095 \\
\hline a. Wilcoxon Signed Ranks Test \\
\hline b. Based on negative ranks.
\end{tabular}

Source: Authors

Wilcoxon test shows a statistically significant difference in the willingness to report between all fraud types except FFS and C cases in the absence of a close relationship between the perpetrator and the whistle-blower $(p=0.181)$. The same test shows that among scenarios 1 and 4, as individual cases of AM, there isn't statistically significant difference in the perception of willingness to report fraud regardless of existence / non-existence of a close relationship between the perpetrator and the whistle-blower ( $p=0,136$ and $p=0,095$ ), while among other fraudulent couples, there is a statistically significant difference in the willingness to report the perpetrator. Previously presented findings lead to the need for additional testing of the existence of differences in observers' willingness to report individual fraud scenarios in the existence / non-existence of close relationships between the perpetrator and the whistle-blower, and the test results were shown in Table 8.

Table 8: Willingness to report perpetrators by paired fraud scenarios in the existence / non-existence of a close relationship between the perpetrator and the whistle-blower

\begin{tabular}{|l|r|r|r|r|r|r|}
\hline \multicolumn{1}{|c|}{ Scenario } & \multicolumn{1}{c|}{$\mathbf{1}$} & \multicolumn{1}{c|}{$\mathbf{2}$} & \multicolumn{1}{c|}{$\mathbf{3}$} & \multicolumn{1}{c|}{$\mathbf{4}$} & \multicolumn{1}{c|}{$\mathbf{5}$} & \multicolumn{1}{c|}{} \\
\hline Z & $-5.316^{\mathrm{b}}$ & $-6.556^{\mathrm{b}}$ & $-4.819^{\mathrm{b}}$ & $-5.254^{\mathrm{b}}$ & $-5.216^{\mathrm{b}}$ & $-4.788^{\mathrm{b}}$ \\
\hline Asymp. Sig. (2-tailed) & .000 & .000 & .000 & .000 & .000 & .000 \\
\hline a. Wilcoxon Signed Ranks Test \\
b. Based on positive ranks.
\end{tabular}


The data presented in Table 8 show that there is a statistically significant difference in the willingness to report the fraud perpetrator, depending on the relationship which the whistle-blower has with the perpetrator of fraud for all fraud scenarios $(\mathrm{p}=$ 0.000 ), with note that the lowest difference in changing of opinion of the observers showed when they should report about FFS cases, perceiving this fraud as the most serious act of violation of the regulatory framework, and regardless of any friendship / family relationship with the perpetrator, observers are ready to report it to the competent authorities for criminal prosecution purposes. Observers' agreement with fraudulent activities were shown in Table 9.

Table 9: Agreement with fraudulent activities

\begin{tabular}{|c|r|r|r|r|r|}
\hline Scenario & N & \multicolumn{1}{|c|}{ Minimum } & Maximum & \multicolumn{1}{c|}{ Mean } & \multicolumn{1}{c|}{ Std. Deviation } \\
\hline 1 & 124 & 1 & 7 & 3.26 & 2.186 \\
\hline 2 & 123 & 1 & 7 & 2.14 & 1.543 \\
\hline 3 & 122 & 1 & 7 & 1.93 & 1.622 \\
\hline 4 & 123 & 1 & 7 & 2.76 & 1.883 \\
\hline 5 & 123 & 1 & 7 & 1.62 & 1.411 \\
\hline 6 & 123 & 1 & 7 & 1.63 & 1.387 \\
\hline
\end{tabular}

\section{Source: Authors}

As expected, the respondents showed the lowest agreement with the FFS activities, and the highest agreement with the AM activities. Here and now, it is possible to compare the findings of this research with the findings of the research by Baird \& Zelin II, that, for the scenarios 1-6, respectively, shows the following mean ratings of observers' compliance with the fraudulent activities in scenarios $3.19 ; 2.47 ; 1.99$; $2.42 ; 2.37$; 1.98. (2008, p.8) Comparison of the given findings shows more rigorous views of $\mathrm{BiH}$ respondents on FFS and $\mathrm{C}$ fraud, while with the $\mathrm{AM}$ frauds respondents in $\mathrm{BiH}$ show a greater agreement. The existence of differences in the level of agreement of the observers with the fraudulent activities described in scenarios was tested by the Friedman test $(p=0.000)$.

Table 10: Agreement with fraudulent activities by paired types and individual scenarios

\begin{tabular}{|l|r|r|r|r|r|r|}
\hline \multirow{2}{*}{ Agreement with frauds } & \multicolumn{3}{|c|}{ Paired fraud types } & \multicolumn{3}{c|}{ Paired fraud scenarios } \\
\cline { 2 - 7 } & FFS-AM & \multicolumn{1}{|c|}{ FFS-C } & \multicolumn{1}{c|}{ C-AM } & \multicolumn{1}{c|}{ S6-S3 } & \multicolumn{1}{c|}{ S5-S2 } & \multicolumn{1}{c|}{ S4-S1 } \\
\hline Z & $-8.081^{\mathrm{b}}$ & $-1.983^{\mathrm{b}}$ & $-7.664^{\mathrm{b}}$ & $-2.409^{\mathrm{b}}$ & $-4.183^{\mathrm{b}}$ & $-1.986^{\mathrm{b}}$ \\
\hline Asymp. Sig. (2-tailed) & .000 & .047 & .000 & .016 & .000 & .047 \\
\hline a. Wilcoxon Signed Ranks Test \\
\hline
\end{tabular}


The Wilcoxon test showed a statistically significant difference in the respondents' agreement with all individual fraud types and individual fraud cases within the same fraud group, and the test confirmed expectations that respondents are ready to do AM fraud rather than FFS, and that they would rather agree with AM activities than C.

The general assumptions are that observers' perception of a high fraud seriousness reflects a low perception of agreement to the fraud committed, while the perception of a high agreement to fraud is reflected in the low willingness to report the fraud, that the perception of the fraud seriousness would go in the same direction as the perception of the willingness to report the fraud. The Spearman correlation test was used for calculating the direction and intensity of the correlation, and its result was shown in Table 11.

Table 11: Correlation analysis of respondents' attitudes

\begin{tabular}{|c|c|c|c|c|c|c|c|c|}
\hline \multicolumn{9}{|c|}{ Correlation between fraud severity (FS) and fraud agreement (FA) } \\
\hline & \multicolumn{2}{|c|}{ FFS } & \multicolumn{2}{|c|}{$\mathbf{C}$} & \multirow{2}{*}{$\begin{array}{c}\mathbf{A M} \\
\mathrm{FS}\end{array}$} & \multirow[b]{2}{*}{ FA } & \multirow{2}{*}{$\begin{array}{c}\text { Total } \\
\text { FS }\end{array}$} & \multirow[b]{2}{*}{ FA } \\
\hline Spearman's rho & FS & FA & FS & FA & & & & \\
\hline Coefficient & 1.000 & $-.596 * *$ & 1.000 & $-.476 * *$ & 1.000 & $-.367 * *$ & 1.000 & $-.522 * *$ \\
\hline Sig. (2-tailed) & & .000 & & .000 & & .000 & & .000 \\
\hline \multicolumn{9}{|c|}{ Correlation between of willingness to report fraud (WRF) and fraud agreement (FA) } \\
\hline & \multicolumn{2}{|c|}{ FFS } & \multicolumn{2}{|c|}{$\mathrm{C}$} & $\mathrm{AM}$ & & Total & \\
\hline Spearman's rho & WRF & FA & WRF & FA & WRF & FA & WRF & FA \\
\hline Coefficient & 1.000 & $-.478 * *$ & 1.000 & $-.333 * *$ & 1.000 & $-.583 * *$ & 1.000 & $-.529 * *$ \\
\hline Sig. (2-tailed) & & .000 & & .000 & & .000 & & .000 \\
\hline \multicolumn{9}{|c|}{ Correlation between fraud severity (FS) and willingness to report fraud (WRF) } \\
\hline & \multicolumn{2}{|c|}{ FFS } & \multicolumn{2}{|c|}{$\mathrm{C}$} & $\mathrm{AM}$ & & Total & \\
\hline Spearman's rho & FS & WRF & FS & WRF & FS & WRF & FS & WRF \\
\hline Coefficient & 1.000 & $.611 * *$ & 1.000 & $.508 * *$ & 1.000 & $.428 * *$ & 1.000 & $.608 * *$ \\
\hline Sig. (2-tailed) & & .000 & & .000 & & .000 & & .000 \\
\hline
\end{tabular}

\section{Source: Authors}

Correlation analysis confirmed that there was a negative correlation between perceived fraud severity and consent, i.e. observers show the higher agreement with fraud which they perceived such as less serious (-0.522), as well as a willingness to report fraud and consent to fraud, actually that respondents are more willing to report fraud they are not ready to commit (-0.529), and positive correlations between the perception of fraud seriousness and willingness to report its, indicating that respondents are more willing to report fraud which they perceive as more serious (0.608). All correlation relationships identified are of moderate intensity. 
The results of hypothesis testing are as follows:

H1: Respondents perceive FFS as a more serious fraud than AM. The mean rating of fraud seriousness was higher for FFS compared to AM $(p=0.000)$. We cannot reject the null hypothesis.

H2: Respondents perceive FFS as a more serious fraud than $C$. The mean rating of fraud seriousness was higher for FFS compared to $C(p=0,000)$. We cannot reject the null hypothesis.

H3: Respondents perceive $C$ as a more serious fraud than AM. The mean rating of fraud seriousness was higher for $C$ compared to $A M(p=0,000)$. We cannot reject the null hypothesis.

H4: Respondents would rather report FFS fraud than AM. The mean rating of willingness to report fraud perpetrators of FFS is higher than AM $(p=0.000)$. We cannot reject the null hypothesis.

H5: Respondents would rather report FFS fraud than $C$. The mean rating of willingness to report the fraud perpetrator is higher for FFS compared to $C(p=0.091)$. The null hypothesis must be rejected.

H6: Respondents would rather report $C$ fraud than $A M$. The mean rating of willingness to report the fraud perpetrator is higher for C compared to AM. $(p=0.000)$. We cannot reject the null hypothesis.

H7: Respondents would rather report fraud when they have not close relationship with the fraud perpetrator, than when they have a close relationship with fraud perpetrator. For each fraud scenario, the mean ratings of willingness to report the fraud perpetrator in the absence of close relationship with the fraud perpetrator are higher than in the case of a close relationship with the perpetrator $(p=0.000)$. We cannot reject the null hypothesis.

H8: Respondents express higher agreement with $A M$ actions than $C$. The mean rating of consent to fraudulent actions is higher for AM compared to $C(p=0.000)$. We cannot reject the null hypothesis.

H9: Respondents express higher agreement with AM actions than FFS. The mean rating of consent with fraudulent actions is higher for AM compared to FFS $(p=0,000)$. We cannot reject the null hypothesis.

H10: Respondents express higher agreement with $C$ actions than FFS. The mean rating of consent to fraudulent actions is higher for C compared to FFS $(p=0.024)$. We cannot reject the null hypothesis. 


\section{CONCLUSION AND RECOMMENDATIONS}

Different research conducted globally show that despite the efforts of numerous regulatory agencies to fraud reduction, frauds represent one of the biggest challenges for companies around the world. The conducted research in $\mathrm{BiH}$, showed that students perceive FFS cases as the most serious fraud in entities, that they are willing to report them to the competent authorities before any other type of fraud, and that they are the least willing to commit such fraud in practice. On the other side, views of the respondents regarding the recognition of $\mathrm{AM}$ and $\mathrm{C}$ cases, indicated that education in the field of understanding various corruption activities should be at a higher level, since it is evident that there is no clear differentiation between the $\mathrm{C}$ and $\mathrm{AM}$ cases. Therefore it is recommended to include more topics from the area of understanding of corrupt activities in the study programs of economic orientations, in order for students to look at the negative effects of these activities on entities, to strengthen the perception of aversion to them, and to increase the willingness to report perpetrators of corrupt activities. An additional recommendation is to enrich the study programs with topics from the ethic area, in order to make students more aware of the importance of ethical behaviour, the benefits of ethics and the implications of unethical behaviour of employees in the overall society. The limitations of the conducted research can be found in a relatively small number of faculties of economy that have conducted research on students' perceptions of fraud (two of eight public universities in $\mathrm{BiH}$ ), and in this sense the authors intend to ensure that more faculties are involved in the future research.

\section{REFERENCES}

1. Albrecht, W. S., Albrecht, C.C., Albrecht, C.O., and Zimbelman, M., 2009. Fraud Examination. 3.edition. South-Western, Cengage Learning.

2. Aljinović Barać, Ž., Markota, Lj., i Vuljan, F., 2016. Važnost etike u obrazovanju i utjecaj na ponašanje profesionalnih računovođa. Zbornik znanstvenih radova sa 17. Međunarodne znanstvene i stručne konferencije Računovodstvo i menadžement, p: 21-30.

3. ACFE, 2010. Report to the Nations 2010 - Global Study on Occupational Fraud and Abuse, [online]. Available at: www.acfe.com [Accessed on October 20,2019.]

4. ACFE, 2012. Report to the Nations 2012 - Global Study on Occupational Fraud and Abuse, [online]. Available at: www.acfe.com [Accessed on October 20,2019.] 
5. ACFE, 2014. Report to the Nations 2014 - Global Study on Occupational Fraud and Abuse, [online]. Available at: www.acfe.com [Accessed on October 20,2019.]

6. ACFE, 2016. Report to the Nations 2016 - Global Study on Occupational Fraud and Abuse, [online]. Available at: www.acfe.com [Accessed on October 20,2019.]

7. ACFE, 2018. Report to the Nations 2018 - Global Study on Occupational Fraud and Abuse, [online]. Available at: www.acfe.com [Accessed on October 20,2019.]

8. Baird, J.E, \& Zelin II, R.C., 2008. Understanding Employee Perceptions of Fraudulent Activities and Their Propensity to Report Those Activities Using Anonymous Tip Lines: The Influence of Fraud Type, Perpetrator Gender, and Observer Demographics, Southern Business Review, Volume 33, Number 1, p.1-14.

9. Baird, J.E, Zelin II, R.C. \& Olson, K.C., 2016. Occupational Fraud: A Comparison of Perceptions of Law Enforcement Majors, Accounting Majors, and Other Business Majors. [online] Journal of Forensic \& Investigative Accounting, Volume 8, Issue 2, Special Issue, Available at: https://pdfs.semanticscholar.org [Accessed on December 19, 2019.]

10. Isaković-Kaplan, Š., 2016. Forenzično računovodstvo. Fojnica: Štamparija Fojnica.

11. Isaković-Kaplan, Š., 2019. Računovodstvena profesija i etika u funkciji reformisanja bh. Privrede. Zbornik radova 20. Međunarodnog simpozija HOPE Revicon, p. 279-292.

12. Pricewaterhouse Coopers, 2018. Global Economic Crime and Fraud Survey 2018, [online]. Available at: www.pwc.com [Accessed on December 24, 2019.] 
Ševala Isaković-Kaplan, $\mathrm{PhD}$

Lejla Demirović, $\mathrm{PhD}$

Mahir Proho, BSc

\section{FINANSIJSKO IZVJEŠTAVANJE PRIVREDNIH DRUŠTAVA I ETIČKE DILEME STUDENATA U BOSNI I HERCEGOVINI}

\section{SAŽETAK}

Fer i pouzdano finansijsko izvještavanje privrednih subjekata izuzetno je važno za jačanje povjerenja među privrednim subjektima, djelujući pozitivno na obim realiziranih poslovnih aktivnosti i ostvarene rezultate. $S$ druge strane, zbog prevara $u$ finansijskim izvještajima privrednih društava, velike gubitke trpe pojedinci, privreda i cijelo društvo, posljedično rušeći povjerenje u računovodstvenu profesiju. Očekivanja javnosti od računovodstvene profesije jesu da njeni profesionalci svjesno odbiju učešće u bilo kakvim prevarnim aktivnostima, te budu istinski borci za istinito finansijsko izvještavanje društava. U svjetlu navedenih očekivanja, predmetni rad nastoji sagledati sposobnost studenata ekonomskog usmjerenja u BiH u prepoznavanju slučajeva lažnog finansijskog izvještavanja među različitim situacijama koje mogu uključivati prevarne karakteristike, kao i njihovu spremnost da uzmu aktivno učešće u borbi protiv prevara u privrednim društvima i privrednog kriminala, općenito. Rezultati istraživanja pokazali su da učesnici istraživanja jasno prepoznaju slučajeve lažnog finansijskog izvještavanja među različitim prevarnim aktivnostima, da imaju visoku izraženu svjesnost u pogledu ozbiljnosti navedene vrste prevare i negativnih posljedica koje ista uzrokuje za društva, te da oni iskazuju bezrezervnu spremnost prijave navedenih slučajeva nadležnim organima za potrebe procesuiranja.

Ključne riječi: finansijski izvještaji, prevara, računovodstvena profesija, etika.

JEL: M49. 